\title{
The impact of mobile banking on the adoption of banking products and services in South Africa, using the technology acceptance model
}

\author{
Moshele Koenaite \\ University of the Witwatersrand, South Africa \\ Tinashe Chuchu \\ University of Pretoria, South Africa \\ Marike Venter de Villiers \\ University of the Witwatersrand, South Africa
}

\begin{abstract}
Keywords
Mobile banking, Customer service, Technology Acceptance Model (TAM)
\end{abstract}

\begin{abstract}
The purpose of the study was to investigate the antecedents of the adoption of mobile banking. A modification of the technology acceptance model (TAM) was adopted in order to test hypothesised relationships. Past literature on mobile banking was reviewed for the study. The study was quantitative in nature whereby 320 respondents participated in an online survey regarding their views on the adoption of mobile banking products and services. Convenience sampling, a form of non-probability sampling was employed for purposes of the study in order to select appropriate participants through the aid of screening questions. The study focused on the perception that customers had towards the use of mobile banking mainly regarding its usefulness as a banking service. Key findings from the study were that intention to use mobile banking was seen to play a prominent role in customer's actual usage of mobile banking. This possibly suggested that customers that already had the intention to use mobile banking ended-up using the service. The relationship strength between the knowledge of mobile banking and perceived usefulness was the equivalent to that of the ease of using of mobile banking and the attitudes towards mobile banking. Perceived usefulness and ease of use were both used as mediators between the knowledge of mobile banking and attitudes towards mobile banking. It was observed that the former had more influence on attitudes than the latter.
\end{abstract}

Corresponding author: Tinashe Chuchu

Email addresses for the corresponding author: tinashe.chuchu@up.ac.za

First submission received: $26^{\text {th }}$ March 2018

Revised submission received: $2^{\text {nd }}$ June 2018

Accepted: $18^{\text {th }}$ July 2018

Introduction and background of the study

With the rise of globalization, banks have been forced to launch new channels to gain a competitive advantage (Mermod, 2015). In fact, they have been under significant pressure to reduce costs and further their financial positions through innovative products and services (Mermod, 2015). As a result, most banks have adopted a multi-channel distribution approach, which has given them a global presence with customers able to access banking services from across borders (Mermod, 2015). An example is the launch of mobile banking. Mobile banking, also referred to as cell phone banking, is the use of mobile terminals such as cell phones and tablets to access banking services (Zhou, Lu \& Wang, 2010). Traditional banks have showed interest to mobile banking due to its ability to facilitate services anywhere at any time (Zhou, Lu \& Wang 2010). Mobile banking technology also allows customers to perform bank transactions anytime and anywhere (Zhou, 2012; Malaquias \& Hwang, 2016). However, Malaquias \& Hwang (2016) cited concerns in that customers need to be able to trust mobile banking services for them to use them since there is the possibility of viruses in mobile terminals. According to Maziriri, Mapuranga and Madinga (2018) the banking sector has great influence since it searches for methods focused on clients that lower costs and enhance effectiveness of services. 
The internet and mobile technologies have penetrated all spheres of human daily activity (Wei, \& Lu, 2014). Furthermore, Wei and $\mathrm{Lu}$ (2014) suggest that these technologies haves also significantly transformed lives and consumer behaviour. Despite the many benefits of digital banking for banks and their clients, penetration in the South African market is low (Maduku, 2013).

Low digital banking penetration is also concerning when comparing penetration rates of cell phones and internet in South Africa, which continues to grow at steady rates, some studies indicate that more people hold cell phones than bank accounts in Sub-Saharan Africa, South Africa included (Asongu, 2013). Banks are constantly searching for ways to increase their profit potential (Masocha, Chiliya \& Zindiye, 2011). Mobile banking technology holds the potential to possibly enhance customer's quality of life while bringing efficiency to banks (Malaquias \& Hwang, 2016). Davis (1989) proposed the Technology Acceptance Model (TAM), which has been adopted in various studies (Gu, Lee, \& Suh, 2009; Maduku, 2011; Cheung \& Vogel, 2013; Shaikh \& Karjaluoto, 2015) to investigate the acceptance of new technology in information systems. Therefore, the present research adapted a modified TAM in order to explore and determine the factors that influence acceptance and usage of technology focusing on mobile banking technologies. The following section will explore the motivation for the present research.

\section{Motivation for Research}

According to Shaikh \& Karjaluoto (2015), mobile banking has emerged as one of the most recent mobile technological marvels. Even though automated teller machines (ATMs), telephone, and internet banking offer effective delivery channels for traditional banking products, the entry of mobile banking on to the market could have significantly positive effects (Safeena, Date, Kammani, \& Hundewale, 2012; Shaikh \& Karjaluoto, 2015). The above literature became the motivation for this research.

\section{Problem Statement and Research Gap}

While some commercial research exists around exact penetration rates, academic research is not extensive enough in this field. According to the Banking Association of South Africa (2015) banking itself as a basic economic function has not reached saturated penetration, with banking services for adults above the age of 16 in South Africa stood at around $80 \%$ as at 2014. While this number is high, it is deceiving, because the growth of the banked population in South Africa has reached relative stagnation (Banking Association of South Africa, 2015).

\section{Research Objectives}

- The research objectives of the study were to analyse the relationship that exists between:

- Knowledge of mobile banking and the perceived usefulness of mobile banking

- Knowledge of mobile banking and ease of using mobile banking

- Perceived usefulness of mobile banking and attitudes towards mobile banking

- Research objectives of this study were to conduct a literature review on the existing knowledge of mobile banking, perceived use and ease of mobile banking. Further research objectives were to review literature on attitudes towards mobile banking, the intention to use mobile banking and ultimately the actual usage of mobile banking.

\section{Theoretical framework}

The section that follows explores the theoretical framework adopted for the current study. The following theories were utilised: the technology acceptance model and the theory of planned behaviour.

\section{Theory of Planned Behaviour (TPB)}

In analysing attitude, which also influences technological acceptance, it is useful to look the Theory of Planned Behaviour. Specifically, this theory looks at how intention is influenced by attitude towards a behaviour, subjective norms as well as perceived behavioural control. The theory of planned behaviour is adapted from the field of social psychology and applicable to various other fields of research is the most established framework for analysing behavioural intentions (Ernst, 2018). 


\section{Theory of Reasoned Action (TRA)}

The theory of reasoned action (Fishbein \& Ajzen, 1975) is the foundation of the TAM (Yen \& Wu, 2016). The TAM, which was introduced by Davis (1989), is widely used to examine the acceptance of new technology in the information system (Yen \& $\mathrm{Wu}, 2016)$. This model recognised the causal relationship among perceived ease of use, perceived usefulness, attitudes, and behavioral intentions toward the use of the technology (Yen \& Wu, 2016).

\section{Technology Acceptance Model (TAM)}

$\mathrm{Gu}$, Lee \& Suh, (2009) stated the TAM has been utilised in the past to explain an individual's acceptance of new Information Technology (IT) and validated that the perceived usefulness and the perceived ease-of-use are central constructs of individual. According to Yen and $\mathrm{Wu}$ (2016) the TAM posits that user acceptance can be explained by two constructs: perceived usefulness and perceived ease of use. In addition, Yen and $\mathrm{Wu}(2016)$ also suggested that the TAM model has been utilised in the fields of information systems, marketing, and electronic commerce. This therefore making makes it relevant to the present study.

\section{Literature review}

Rapid developments in mobile technologies and devices have made mobile banking central aspect of commerce and financial services (Lin, 2011). Laukkanen (2007) and Lin (2011) viewed mobile banking can be treated as a technological advancement since it enables customers to carry-out banking transactions without constraints of time and place and location. Furthermore, customers are allowed are also able to conveniently connect to banking services easily and fast with mobile devices (Laukkanen, 2007; Gu et al., 2009; Lin, 2011). Luo, Li, Zhang \& Shim (2010) posited that the banking sector is among the most proactive industries in terms of adopting internet and mobile technology for consumer markets. Electronic banking has revolutionised business of retail banks significantly as far as the minimisation of costs and the increase of increase of convenience to the consumer is concerned (Luo et al., 2010). Most banks throughout Europe, the United States of America and Asia have provided their customers mobile access to financial services (Gu et al., 2009). Mobile Banking in South Africa

With one of the most sophisticated telecommunication infrastructures of all the emerging markets, mobile banking is one of the many innovative new services that South Africa has witnessed (Joubert \& Van Belle, 2013). More than $90 \%$ of the South African population owns a mobile phone which is an extraordinary penetration rate in this burgeoning market making it one of the highest in the developing world (Wireless Federation, 2008). As a result, there seems to be a general consensus that Africa could become a key player in penetrating the E-commerce market and therefore excel in the adoption of $\mathrm{M}$ commerce (Joubert \& Van Belle, 2013). South Africa's M-commerce industry consists of a three-tier model (Joubert \& Van Belle, 2009).

The section that follows presents the research conceptual model illustrating all the hypothesised relationships and their development.

The present research makes use of the modified adaption of the TAM. Based on review of past studies that utilised or made reference to the TAM (Gu et al., 2009; Luo, Li, Zhang, \& Shim, 2010; Zhou Ta, Lu \&, Wang, 2010) the researcher decided to use the TAM as the base of this research. In the hypothesised conceptual model knowledge of mobile banking (KMB) is the predictor variable, perceived usefulness (PU) and ease of using mobile banking (EMB), attitudes towards mobile baking (ATT) and intention to use mobile banking (IMB) are the mediator variables. The research conceptual model is presented in the following section. 
Figure 1: Research Conceptual Model

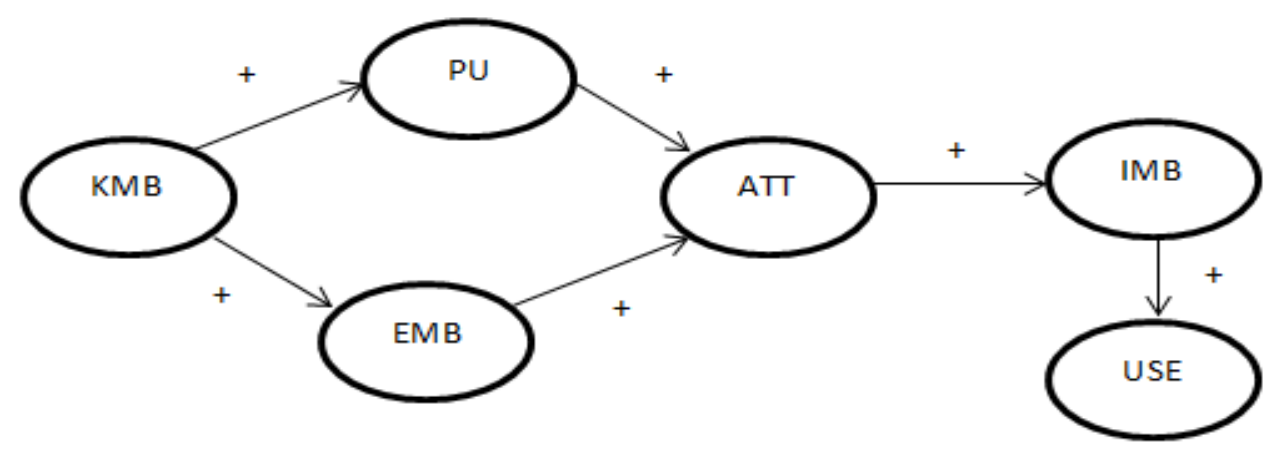

Key: KMB: Knowledge of mobile banking, PU: Perceived usefulness; EMB: Ease of using mobile banking; ATT: Attitudes towards mobile banking; IMB: Intention to use mobile banking: USE: Actual usage of mobile banking

\section{Hypotheses Development}

This section presents development of the hypothesised relationships based on a modified version of the technology acceptance model.

\section{Knowledge of mobile banking and the perceived usefulness of mobile banking}

Customer familiarity with a bank's products and services such as mobile banking will positively influence perceived usefulness of mobile banking (Gu et al., 2009). However, Gu et al. (2009), added on to state that the relationship between mobile banking and perceived usefulness is mediated by the perceived ease of use of mobile banking. Therefore, inferring from the literature and the empirical findings abovementioned it can be hypothesised that:

H1: Knowledge of mobile banking is directly and positively related to the perceived usefulness of mobile banking

\section{Knowledge of mobile banking and ease of using mobile banking}

According to Gu et al. (2009), the extent to which customers are familiar to a bank and its services such as mobile banking will directly and positively influence the ease of using mobile banking. Additional for knowledge of the bank's products and services will also influence customer trust positively (Gu et al., 2009). Therefore, it can be deduced that:

H2: Knowledge of mobile banking influences the ease of using mobile banking directly and positively.

Perceived usefulness of mobile banking and attitudes towards mobile banking

According to Lin perceived usefulness of mobile banking is directly and positively related to attitudes towards accepting mobile banking (Lin, 2011). In addition, Shaikh, Glavee-Geo and Karjaluoto (2015) also suggested that the ease of using mobile devices is directly and positively linked to attitudes towards mobile banking. Therefore, inferring from the literature and the empirical evidence abovementioned, the study postulates that:

H3: Perceived usefulness of mobile banking impacts attitudes towards mobile banking.

\section{Ease of using mobile banking and attitudes towards mobile banking}

Shaikh et al. (2015) posited that the ease of using mobile is directly and positively liked to attitude towards mobile banking. In their study Cheung and Vogel (2013) also suggested that the ease of using technology will directly influence customer attitudes towards use of that technology in a positive manner. Therefore, concluding from the literature and the empirical evidence abovementioned, the study hypothesizes that:

H4: Ease of using mobile banking affects attitudes towards mobile banking

\section{Attitudes towards mobile banking and intention to use mobile banking}

According to Lin (2011), attitude has towards the adoption of mobile banking have a positive and direct influence on the intention to used mobile banking. Attitudes that customers have towards 
technology positively impact the intention to use that technology according to (Cheung \& Vogel, 2013). Therefore, inferring from the literature and the empirical evidence abovementioned, the study assumes that:

H5: Attitudes towards mobile banking and intention to use mobile banking are positively and directly related

\section{Intention to use mobile banking and actual usage of mobile banking}

According to Shaikh et al. (2015) the intention to use mobile banking and adoption of mobile banking are directly and positively associated. The intention to use technology will lead to consumers' actual adoption or use of that technology (Cheung \& Vogel, 2013). Therefore, making assumptions based on prior literature it can be suggested that:

H6: Intention to use mobile banking will directly and positively influence the actual usage of mobile banking

\section{Research design and methodology}

According to Malhotra and Birks (2007) a research design is a procedure of information collection, analysis and the implications of the findings established.

\section{Target Population}

As it is not possible to survey the entire bankable population in South Africa therefore obtaining a sample frame was not possible due to cost and practicality, a sample that reasonably and practically represents this broader population was be sought. The target population for the questionnaire used was South Africans, currently banked or interested in banking facilities or accounts, aged between 18 and 35 years old.

\section{Sampling Method and Sample Size}

The sampling method adopted for this study was convenience sampling, a non-probability. Due to a sample frame not being available past research in the same field was consulted. To determine an appropriate sample past research was consulted for example those that had a sample size exceeding 300 respondents for example (Maduku, 2013). The present study utilised 320 surveys. This value was also close to the recommended sample size by Rasoft (2017), a sample size calculator which recommends 381 for any population above 20 000. In addition, further justification for sample size was from Maduku (2013) who used 300 participants where an exact sample size could not be determined.

Measurement Instrument Development

The research scales were operationalised mainly on the basis of existing scales. Adequate modifications were made in order to fit the research context for the purpose of the present article. Fivepoint Likert scales were employed to analyse items of the research instrument. The research instrument was divided into seven parts. The first part focused on biographical information. The second section was on knowledge of mobile banking adapted from (Gu et al., 2009), the third section was on the usefulness of mobile banking taken from (Mohammadi, 2015) and the fourth section on the ease of using mobile banking adapted from (Mohammadi, 2015). The fifth section was on attitudes towards mobile banking while the sixth part was on the intentions of using mobile banking adapted from (Nasri \& Lanouar, 2012; Mohammadi, 2015). The last section was developed from questions on the actual use of use of mobile banking adapted from Mohammadi (2015).

\section{Findings}

This section presents the results of the present study. Demographic statistics, reliability and validity statistics, model fit checks as well as hypothesis testing was conducted.

Table 1: Sample profile

\begin{tabular}{|l|l|l|l|l|l|l|}
\hline Gender & Frequency & Percentage & Residential Area & Frequency & Percentage \\
\hline Male & 149 & 45.8 & Rural & 10 & 3.1 \\
\hline Female & 175 & 53.8 & Urban & 315 & 96.9 \\
\hline Prefer not to say & 1 & 0.3 & Total & 325 & 100 \\
\hline Total & 325 & 100 & & & \\
\hline
\end{tabular}




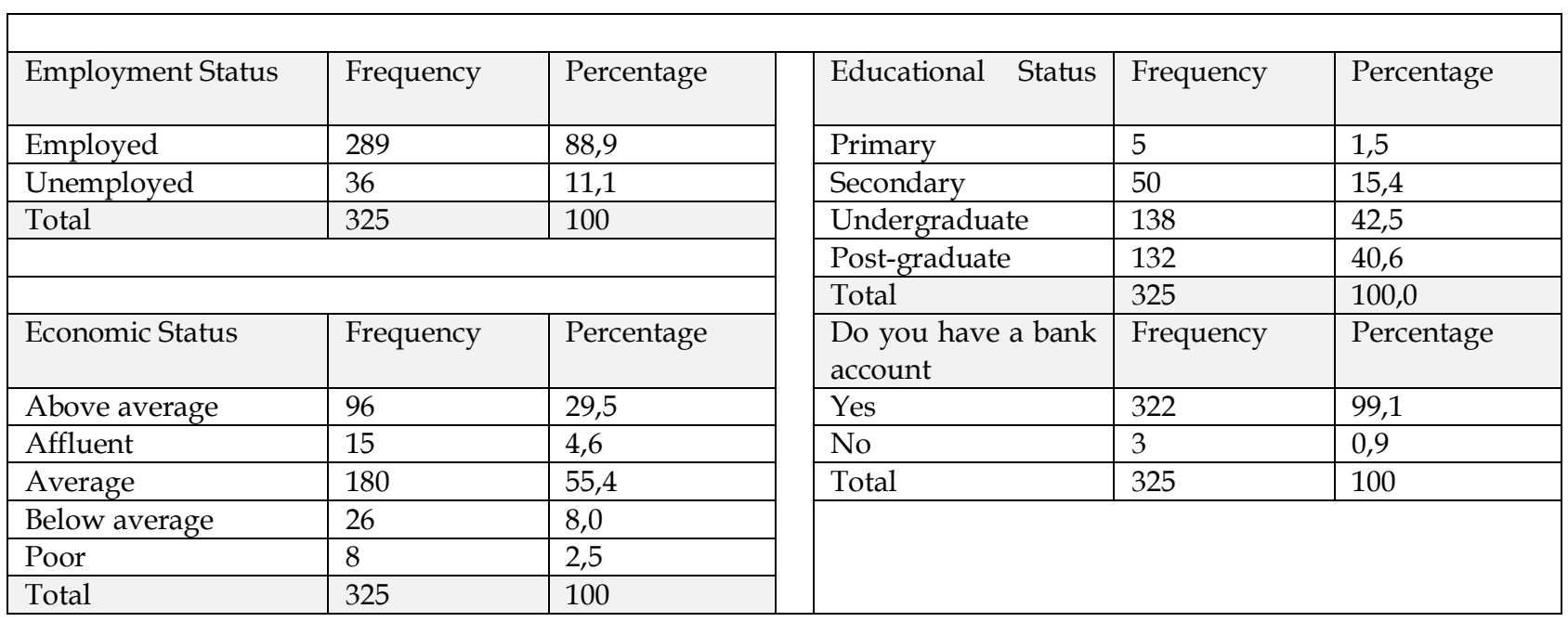

\section{Data analysis approach}

Structural Equation Modeling has emerged as one of chief research data analysis techniques of choice for researchers across disciplines (Hooper, Coughlan \& Mullen, 2008). Structural equation modeling approach was adopted to analyse the research data of the present study whereby the proposed hypotheses were tested.

\section{Reliability Checks}

The Cronbach's alpha, item to total values and composite reliability values were calculated in order to the check for reliability of the measurement scales.

\section{Discriminant Validity Check}

As indicated in Table 2, the inter-construct correlation values for all paired latent variables fell below the threshold recommended by (Pooe, Mafini \& Loury-Okoumba, 2015) to prove the existence of discriminant validity. Discriminant validity confirms that a construct is empirically distinct from other measures in the same structural equation model (Hair, Black, Babin \& Anderson, 2010; Henseler, Ringle \& Sarstedt, 2015). In the following section the inter-construct correlation matrix is presented.

Table 2: Inter-construct Correlation Matrix

\begin{tabular}{|l|l|l|l|l|l|l|}
\hline & KMB & PU & EMB & ATT & IMB & USE \\
\hline KMB & 1 & & & & & \\
\hline PU & $0.737^{* *}$ & 1 & & & & \\
\hline EMB & $0.523^{* *}$ & $0.591^{* *}$ & 1 & & & \\
\hline ATT & $0.556^{* *}$ & $0.569^{* *}$ & $0.613^{* *}$ & 1 & & \\
\hline IMB & $0.455^{* *}$ & $0.482^{* *}$ & $0.421^{* *}$ & $0.534^{* *}$ & 1 & \\
\hline USE & $0.595^{* *}$ & $0.600^{* *}$ & $0.472^{* *}$ & $0.651^{* *}$ & $0.672^{* *}$ & 1 \\
\hline$*$ Correlation is significant at the 0.01 level (2-tailed). \\
\hline
\end{tabular}

Key: KMB: Knowledge of mobile banking, PU: Perceived usefulness; EMB: Ease of using mobile banking; ATT: Attitudes towards mobile banking; IMB: Intention to use mobile banking: USE: Actual usage of mobile banking

Illustrated below are the accuracy analysis statistics presented in table 3.

Table 3: Accuracy Analysis Statistics

\begin{tabular}{|c|c|c|c|c|c|c|c|c|c|}
\hline \multirow{2}{*}{\multicolumn{2}{|c|}{ Research Construct }} & \multicolumn{4}{|c|}{ Descriptive Statistics } & \multicolumn{2}{|c|}{ Cronbach's Test } & \multirow{2}{*}{$\begin{array}{l}\text { C.R. } \\
\text { Value }\end{array}$} & \multirow{2}{*}{$\begin{array}{l}\text { Factor } \\
\text { Loading }\end{array}$} \\
\hline & & \multicolumn{2}{|c|}{ Mean Value } & \multicolumn{2}{|c|}{$\begin{array}{l}\text { Standard } \\
\text { Deviation }\end{array}$} & $\begin{array}{l}\text { Item- } \\
\text { total }\end{array}$ & a value & & \\
\hline \multirow[t]{3}{*}{ KMB } & KMB1 & 4.449 & \multirow[t]{3}{*}{4.172} & 0.825 & \multirow[t]{3}{*}{0.931} & 0.765 & \multirow[t]{3}{*}{0.890} & \multirow[t]{3}{*}{0.903} & 0.847 \\
\hline & KMB2 & 4.231 & & 0.936 & & 0.859 & & & 0.939 \\
\hline & KMB3 & 4.065 & & 0.955 & & 0.821 & & & 0.888 \\
\hline
\end{tabular}




\begin{tabular}{|c|c|c|c|c|c|c|c|c|c|}
\hline & KMB4 & 4.252 & & 0.901 & & 0.741 & & & 0.777 \\
\hline & KMB5 & 3.865 & & 1.039 & & 0.520 & & & 0.548 \\
\hline PU & PU1 & 4.058 & 4.251 & 0.885 & 0.904 & 0.606 & 0.785 & 0.846 & 0.793 \\
\hline & PU2 & 4.443 & & 0.782 & & 0.697 & & & 0.743 \\
\hline & PU3 & 4.397 & & 0.827 & & 0.640 & & & 0.671 \\
\hline & PU4 & 4.105 & & 1.123 & & 0.492 & & & 0.537 \\
\hline EMB & EMB1 & 3.206 & 3.708 & 1.082 & 0.965 & 0.546 & 0.767 & 0.753 & 0.512 \\
\hline & EMB2 & 3.932 & & 0.953 & & 0.525 & & & 0.663 \\
\hline & EMB3 & 3.631 & & 1.000 & & 0.655 & & & 0.610 \\
\hline & EMB4 & 4.065 & & 0.823 & & 0.566 & & & 0.828 \\
\hline ATT & ATT1 & 4.505 & 4.064 & 0.651 & 0.924 & 0.534 & 0.784 & 0.767 & 0.742 \\
\hline & $\begin{array}{l}\text { ATT2 } \\
\end{array}$ & 4.098 & & 0.995 & & 0.558 & & & 0.650 \\
\hline & ATT3 & 4.086 & & 0.952 & & 0.522 & & & 0.580 \\
\hline & ATT4 & 3.742 & & 0.991 & & 0.603 & & & 0.576 \\
\hline & ATT5 & 3.889 & & 1.033 & & 0.624 & & & 0.597 \\
\hline IMB & IMB1 & 4.502 & 4.354 & 0.768 & 0.900 & 0.573 & 0.741 & 0.720 & 0.533 \\
\hline & IMB2 & 4.498 & & 0.856 & & 0.499 & & & 0.449 \\
\hline & IMB3 & 4.449 & & 0.851 & & 0.576 & & & 0.788 \\
\hline & IMB4 & 3.908 & & 1.164 & & 0.378 & & & 0.419 \\
\hline & IMB5 & 4.415 & & 0.859 & & 0.576 & & & 0.693 \\
\hline USE & USE1 & 4.588 & 4.436 & 0.621 & 0.801 & 0.745 & 0.855 & 0.883 & 0.835 \\
\hline & USE2 & 4.489 & & 0.804 & & 0.579 & & & 0.629 \\
\hline & USE3 & 4.471 & & 0.760 & & 0.761 & & & 0.857 \\
\hline & USE4 & 4.117 & & 1.082 & & 0.586 & & & 0.629 \\
\hline & USE5 & 4.517 & & 0.739 & & 0.809 & & & 0.898 \\
\hline
\end{tabular}

Key: KMB: Knowledge of mobile banking, PU: Perceived usefulness; EMB: Ease of using mobile banking; ATT: Attitudes towards mobile banking; IMB: Intention to use mobile banking: USE: Actual usage of mobile banking

In table 3 above it can be observed that most of the factor loadings were above 0.5 as recommended by (Chinomona, Lin, Wang \& Cheng, 2010). There was evidence of fair distribution of data as indicated by mean values all being in the 3 to 4 range. As for reliability the all of Cronbach's alpha values exceeded 0.6 as recommended by (Atashzadeh-Shoorideh \& YaghmaeI, 2016) who stated that any value lower than 0.6 indicates unsatisfactory reliability. The composite reliability values ranged from. As for the average variance extracted values (AVE) they ranged from 0.7 to 0.8 exceeding the 0.5 that had been recommended by (Fraering \& Minor, 2006). 


\section{HYPOTHESIS TESTING}

Figure 1: Structural Model

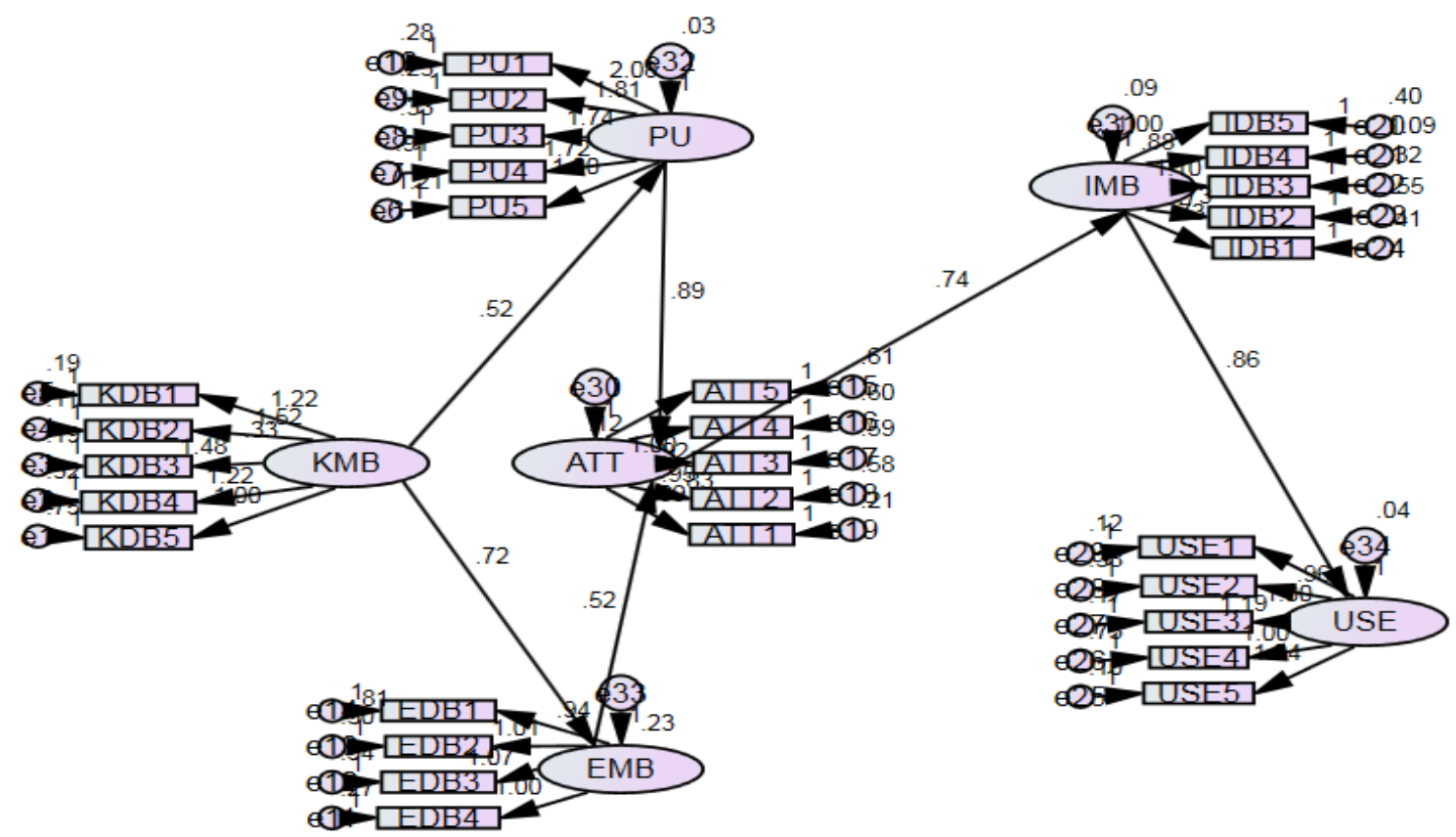

Key: KMB: Knowledge of mobile banking, PU: Perceived usefulness; EMB: Ease of using mobile banking; ATT: Attitudes towards mobile banking; IMB: Intention to use mobile banking: USE: Actual usage of mobile banking

The section that follows explores the hypothesised relationships of the study. Relationship between Knowledge of mobile banking (KMB), Perceived usefulness (PU), Ease of using mobile banking (EMB), Attitudes towards mobile banking (ATT), Intention to use mobile banking (IMB) and Actual usage of mobile banking (USE). These relationships are presented in table 4 on the following page.

Table 4: Hypotheses Table

\begin{tabular}{|c|c|c|c|c|}
\hline $\begin{array}{l}\text { Hypothesised } \\
\text { Relationship }\end{array}$ & Hypothesis & Path Coefficient & P-Value & Outcome \\
\hline $\begin{array}{c}\mathrm{KMB} \\
+ \\
+\end{array}$ & $\mathrm{H} 1$ & 0.52 & $* * *$ & $\begin{array}{l}\text { Supported and } \\
\text { significant }\end{array}$ \\
\hline$\underset{+}{\mathrm{KMB}} \underset{+\mathrm{EMB}}{\rightarrow}$ & $\mathrm{H} 2$ & 0.72 & $* * *$ & $\begin{array}{l}\text { Supported and } \\
\text { significant }\end{array}$ \\
\hline $\begin{aligned} & \rightarrow \text { PU } \\
&+\end{aligned}$ & $\mathrm{H} 3$ & 0.89 & $* * *$ & $\begin{array}{l}\text { Supported and } \\
\text { significant }\end{array}$ \\
\hline $\begin{aligned} \text { EMB } & \rightarrow \text { ATT } \\
& +\end{aligned}$ & $\mathrm{H} 4$ & 0.52 & $* \star *$ & $\begin{array}{l}\text { Supported and } \\
\text { significant }\end{array}$ \\
\hline ATT $\underset{+}{\rightarrow}$ IMB & H5 & 0.74 & $* * *$ & $\begin{array}{l}\text { Supported and } \\
\text { significant }\end{array}$ \\
\hline IMB $\underset{+}{\rightarrow}$ USE & H6 & 0.86 & $* * *$ & $\begin{array}{l}\text { Supported and } \\
\text { significant }\end{array}$ \\
\hline
\end{tabular}

Level of significance $(P<0.001 ; 0.05$ and 0.1$)$

Key: KMB: Knowledge of mobile banking, PU: Perceived usefulness; EMB: Ease of using mobile banking; ATT: Attitudes towards mobile banking; IMB: Intention to use mobile banking: USE: Actual usage of mobile banking

\section{Discussion of Hypotheses}

It can be observed in that all the six hypothesised relationships were supported as we as significant at the $\mathrm{p}<0.001$ level of significance. H1 (Knowledge of mobile banking and Perceived usefulness) at 0.89 had the second strongest relationship. This relationship was both supported and significant at the $\mathrm{p}<0.001$ level of significance. This implied that the more customers had knowledge of mobile banking the more they perceived it to be useful. H2 (Knowledge of mobile banking and ease of using mobile banking) had a 
path coefficient of 0.72 . This relationship was also supported and significant at the $p<0.001$ level of significance suggesting that the more customers know about mobile banking the more they became acquainted. This possibly meant that customers perceive mobile banking as easy to after regular usage.

H3 (Perceived usefulness and attitude towards mobile banking) were positively co-related with a path coefficient of 0.89 . This relationship was both supported and significant at the $\mathrm{p}<0.001$ level of significance implying that consumers attitudes towards mobile banking become more positive if the perceive it to be useful. It should be noted that of all the proposed relationships it was the strongest possibly suggesting customer perceptions of mobile banking's usefulness are heavily dependent on the attitudes they hold towards mobile banking. This implies that the more customers perceive mobile banking to be useful the more they are willing to develop positive attitudes towards mobile banking. The remaining hypotheses $\mathrm{H} 4, \mathrm{H} 5$ and $\mathrm{H} 6$ were also supported and significant at the p<0.001 level of significance.

H4 (ease of using mobile banking and attitudes towards mobile banking) had a path coefficient 0.52. H5 (attitude towards mobile banking and intention to use mobile banking) had a high path coefficient of 0.74 . This suggested that customers who had a positive perception of mobile banking were more inclined towards actually using it. Lastly, H6 (intention to use mobile banking and the actual usage of mobile banking). The relationship had a path coefficient of 0.86 positing that customers who have positive perceptions towards mobile banking will very much likely use it.

\section{Conclusions}

The purpose of this study was to examine the impact of mobile banking on the adoption of banking products and services in South Africa, using the technology acceptance model. A modified technology acceptance model was utilised in measuring hypothesised relationships that could potentially measure the adoption of mobile banking in South Africa. A central theme that could be taken from the study was that the perceived usefulness of mobile banking and the attitudes towards mobile banking (H3) was the strongest of all relationships. This suggested that that the more mobile banking customers are view mobile banking as a useful service the more likely they would actual adopt it, (see table 2), this was the most correlated relationship at 0.672 as well has the relationship with the highest path coefficient of 0.97 , (see table 3). This research established that penetration levels of mobile banking knowledge were low. This finding was similar to that of prior research by Laforet and Li (2005) who found that barriers to mobile banking adoption were a result of low mobile banking awareness. This finding was also supported by Zhou et al (2010) who suggested that mobile banking usage was significantly lower in comparison to other mobile services.

\section{Academic and Managerial Implications}

The present study provides some academic as well as managerial implications for practitioners. First, the modified TAM adapted for this study provides new insights for academicians on the relationships that exist among the variables tested. The conceptual model provided evidence that the single most important relationship in the adoption of mobile banking was the one that existed between intention and the actual adaption. While on the same point marketing managers are to also take note of the fact that intention and actual usage is the most important relationship of the study. This implies that marketing managers should direct most of their efforts into increasing intention to use mobile banking as it has great impact on the actual usage of mobile banking. This could be done by possibly implementing heavy advertising or more convincing advertising in order to stimulate intention to use mobile banking.

\section{Limitations}

Possible limitations of the study were financial and time constraints that could have compromised the overall contribution of the study. Attitudes towards mobile banking (ATT) and the actual usage of mobile banking (USE) is a potentially a hypothesis that could have been assessed (see figure 2). This could have potential provided important insights and analysis possibly affecting the outcomes of the other relationships and the entire model overall. A noticeable limitable was that the rural population in this study was under represented and this reflects what Mashocha et al. (2011) stated. Mashocha et al. (2011) stated that rural areas are under researched as far as electronic-banking (e-banking) is concerned. 


\section{Significance and Overall Contribution of the Study}

The significance of the study is that it introduced a new approach to testing the technology acceptance model within the context of mobile banking. The study contributed new knowledge and understanding through the findings in that all proposed hypothesis were supported and significant and therefore future researchers could use this study as a base. Multiple observations were made however the study introduced to significant contributions to the existing body of knowledge. First, the knowledge of mobile banking had a stronger impact on perceived ease of use (indicated by a path coefficient of 0.72) compared to the impact it had on perceived usefulness (indicated by a path coefficient of 0.52). Knowledge of mobile banking used both perceived usefulness and ease of use as mediators towards attitudes. However, it was observed that perceived usefulness would have a stronger influence on attitudes (indicated by a path coefficient of 0.89 ) than the influence ease of use would have on attitudes (indicated by a path coefficient of 0.52 ).

Second, it was also interesting to find out that the relationship strength between the knowledge of mobile banking and perceived usefulness (path coefficient of 0.52) was exactly the same as that of the ease of using of mobile banking and the attitudes towards mobile banking (path coefficient of 0.52). The following section explores possible options for future researchers in greater depth.

\section{Suggestions for Future Research}

This study was largely skewed towards urban respondents. Future studies should provide a larger rural sample of mobile banking users as this could make for a potential comparative study with a representative balanced sample size as far as rural and urban responses are concerned. The present research did not analyse the relationships between [perceived usefulness (PU) and intention to use mobile banking (IMB)], [(attitudes towards mobile baking (ATT) and actual usage of mobile banking (USE)] and lastly, [(ease of use of mobile banking EMB and actual usage of mobile banking USE)] (see figure 2). Empirical investigation of these relationships could potentially provide useful insights on attitudes and adoption of mobile banking services within a South African context.

\section{References}

Atashzadeh-Shoorideh, F., \& YaghmaeI, F., (2016). Development and Psychometric Evaluation of Scales: A Survey of Published Articles. Journal of Medical Education 14 (4), 174-205

Banking Association of South Africa (2015). FinScope South Africa 2014. THE

Banking Association South Africa - Annual Review 2014. Retrieved, March 12, 2016, from http://www.banking.org.za/news-media/publications/annual-review

Cheung, R., \& Vogel, D. (2013). Predicting user acceptance of collaborative technologies: An extension of the technology acceptance model for e-learning. Computers \& Education, 63, 160-175.

Chinomona, R., \& Pretorius, M. (2011). Major dealers' expert power in distribution channels. South African Journal of Economic and Management Sciences, 14(2), 170-187

Chinomona, R., Lin, J. Y. C., Wang, M. C. H., \& Cheng, J. M. S. (2010). Soft power and desirable relationship outcomes: the case of Zimbabwean distribution channels. Journal of African Business, 11(2), 182-200.

Connaway, S.L. \& Powel, R.R. (2010). Basic research methods for librarians. New York: ABC-CLIO, LLL - Greenwood Publishing Group

Davis, F. D. (1989). Perceived usefulness, perceived ease of use, and user acceptance of information technology. MIS quarterly, 319-340.

Ernst, K. (2018). Heart over mind-An empirical analysis of social entrepreneurial intention formation on the basis of the theory of planned behaviour (Doctoral dissertation, Universität Wuppertal, Fakultät für

Wirtschaftswissenschaft/Schumpeter School of Business and Economics» Dissertation)

Fraering, M., \& Minor, M. S. (2006). Sense of community: An exploratory study of US consumers of financial services. International Journal of Bank Marketing, 24(5), 284-306.

Gu, J. C., Lee, S. C., \& Suh, Y. H. (2009). Determinants of behavioral intention to mobile banking. Expert Systems with Applications, 36(9), 11605-11616.

Hooper, D., Coughlan, J., \& Mullen, M (2008). Structural Equation Modelling: Guidelines for Determining Model Fit. Electronic Journal of Business Research Methods, 6(1), 53-60.

Joubert, J. \& Van Belle, J. (2013). The role of trust and risk in mobile commerce adoption within South Africa. International Journal of Business, Humanities and Technology, 3(2), 27-38.

Laukkanen, T. (2007b). Measuring mobile banking customers' channel attribute preferences in service consumption. International Journal of Mobile Communications, 5 (2), 123-138. 
Laforet, S., \& Li, X. (2005). Consumers' attitudes towards online and mobile banking in China. International journal of bank marketing, 23(5), 362-380.

Lin, H. F. (2011). An empirical investigation of mobile banking adoption: The effect of innovation attributes and knowledge-based trust. International Journal of Information management, 31(3), 252-260.

Luo, X., Li, H., Zhang, J., \& Shim, J. P. (2010). Examining multi-dimensional trust and multi-faceted risk in initial acceptance of emerging technologies: An empirical study of mobile banking services. Decision support systems, 49(2), 222-234.

Maduku, D. K. (2011). Understanding Retail Bank Customers' Attitude Towards and Usage of Cell Phone and Internet Banking Services in Gauteng, South Africa Doctoral dissertation, University of Johannesburg).

Malaquias, R. F., \& Hwang, Y. (2016). An empirical study on trust in mobile banking: A developing country perspective. Computers in Human Behavior, 54, 453-461.

Malhotra, N. \& Peterson, M., (2006). Basic Marketing Research: A Decision-Making Approach, second edition. New Jersey: Pearson Prentice Hall.

Masocha, R., Chiliya, N., \& Zindiye, S. (2011). E-banking adoption by customers in the rural milieus of South Africa: A case of Alice, Eastern Cape, South Africa. African Journal of Business Management, 5(5), 1857- 1863

Maziriri, E.T., Mapuranga, M. \& Madinga, N.W., (2018), 'Self-service banking and financial literacy as prognosticators of business performance among rural small and medium-sized enterprises in Zimbabwe', Southern African Journal of Entrepreneurship and Small Business Management 10(1), 1-10

Mermod, A. Y. (2011). Customer's Perspectives and Risk Issues on E-Banking in Turkey; Should We Still be Online? Journal of Internet Banking and Commerce, 16(1), 1-15

Mohammadi, H. (2015). A study of mobile banking loyalty in Iran. Computers in Human Behavior, 44, 35-47.

Nasri, W., \& Charfeddine, L. (2012). Factors affecting the adoption of Internet banking in Tunisia: An integration theory of acceptance model and theory of planned behavior. The Journal of High Technology Management Research, 23(1), 1-14.

Pooe, D., Mafini, C., \& Loury-Okoumba, V. W. (2015). The influence of information sharing, supplier trust and supplier synergy on supplier performance: The case of small and medium enterprises. Journal of Transport and Supply Chain Management, 9(1), 1-11.

Raosoft (2017) Sample size calculator retrieved from http://www.raosoft.com/samplesize.html accessed 04/06/2018

Raykov, T., \& Marcoulides, G. A. (2004). Using the delta method for approximate interval estimation of parameter functions in SEM. Structural Equation Modeling, 11(4), 621-637.

Safeena, R., Date, H., Kammani, A., \& Hundewale, N. (2012). Technology adoption and Indian consumers: study on mobile banking. International Journal of Computer Theory and Engineering, 4(6), 1020-1024

Shaikh, A. A., Glavee-Geo, R., \& Karjaluoto, H. (2015). An Empirical Investigation of Mobile Banking Services Adoption in Pakistan. World Academy of Science, Engineering and Technology, International Journal of Social, Behavioral, Educational, Economic, Business and Industrial Engineering, 9(11), 3609-3617.

Shaikh, A. A., \& Karjaluoto, H. (2015). Mobile banking adoption: A literature review. Telematics and Informatics, 32(1), 129-142.

Singh, A.M. (2004). Trends in South African Internet banking. New Information Perspective, 56(3), 187-196.

Wei, P. S., \& Lu, H. P. (2014). Why do people play mobile social games? An examination of network externalities and of uses and gratifications. Internet Research, 24(3), 313-331.

Weidemann, R. (2004). WASPA finalising code of conduct. IT Web. 2 May 2004.Wireless Federation, (2008). South Africa rated as world's fourth fastest growing mobile market. Wireless News, 12 November 2008. [Online] Available:https:/ / wirelessfederation.com/news/south-africa-rated-as-worlds-fourth-fastest- growing-mobilemarket [Accessed 28 Dec 2012].

Yen, Y. \& Wu, F. (2016). Predicting the adoption of mobile financial services: The impacts of perceived mobility and personal habit. Computers in Human Behaviour (65), 31-42

Zhou, T., Lu, Y., \& Wang, B. (2010). Integrating TTF and UTAUT to explain mobile banking user adoption. Computers in human behaviour, 26(4), 760-767.

Zhou, T. (2012). Understanding users' initial trust in mobile banking: An elaboration likelihood perspective. Computers in Human Behavior, 28(4), 1518-1525. 